\title{
Rare earth elements in hydrothermal fluids from Kueishantao, off northeastern Taiwan: Indicators of shallow-water, sub-seafloor hydrothermal processes
}

\author{
WANG XiaoYuan ${ }^{1 *}$, ZENG ZhiGang $^{1}$, CHEN Shuai $^{1}$, YIN XueBo $^{1} \&$ \\ CHEN Chen-Tung Arthur ${ }^{2}$ \\ ${ }^{1}$ Key Laboratory of Marine Geology and Environment, Institute of Oceanology, Chinese Academy of Sciences, Qingdao 266071, China; \\ ${ }^{2}$ Institute of Marine Geology and Chemistry, Sun Yat-Sen University, Kaohsiung 80424, Taiwan, China
}

Received November 1, 2012; accepted March 4, 2013; published online May 9, 2013

\begin{abstract}
The rare earth element (REE) geochemistry of hydrothermal vent systems has been investigated intensively, but few studies have been carried out on marine shallow-water hydrothermal systems like that at Kueishantao. Here we present novel data sets of REE in hydrothermal fluids from Kueishantao, off northeastern Taiwan. The total REE ( $\mathrm{REE}$ ) concentrations of yellowish fluids are similar to those of whitish fluids, 813-1212 ng/L, and are significantly higher than that of ambient seawater. The yellowish fluids have chondrite-normalized REE $\left(\operatorname{REE}_{\mathrm{N}}\right)$ distribution patterns with slight convex-downward curvatures at Eu; and the REE patterns of the whitish fluids are smooth at Eu, which is related to the lower temperature and more oxidizing conditions. The Kueishantao hydrothermal fluids are slightly enriched in light REE (La-Nd) relative to the heavy REE (Gd-Lu). The behaviors of REE in both yellowish and whitish fluids are affected by the short time of water-rock interaction. The REE distributions in the yellowish fluids are also affected by very low $\mathrm{pH}$ (2.81 and 2.29), boiling of the fluid and precipitation of native sulfur. In the whitish fluids, adsorption by small particles and formation of REE-chloride complexes has played a role in the distribution of REE.
\end{abstract}

rare earth element, hydrothermal fluid, shallow water, Kueishantao hydrothermal field, off northeastern Taiwan

Citation: Wang X Y, Zeng Z G, Chen S, et al. Rare earth elements in hydrothermal fluids from Kueishantao, off northeastern Taiwan: Indicators of shallow-water, sub-seafloor hydrothermal processes. Chin Sci Bull, 2013, 58: 4012-4020, doi: 10.1007/s11434-013-5849-4

As is well known, rare earth elements have unique similarity of chemical properties. They constitute a coherent group of elements and are thought not to be decoupled in geochemical processes, although the valence change of some elements (such as $\mathrm{Ce}$ and $\mathrm{Eu}$ ) under special circumstances and the filling of inner $4 \mathrm{f}$ electron shells, leading to diminution of the atomic radius (lanthanide compression) in the REE series, do cause some differences during migration processes [1-3]. In aqueous systems, REE can be used as an important basis for identifying the source of the water [4-7]. The fractionation of the REE has been used extensively to trace many geochemical processes associated with hydrothermal

*Corresponding author (email: wangxiaoyuan@qdio.ac.cn) activity, including water-rock interaction in hydrothermal systems [8-11], the evolution of hydrothermal fluids [12], degassing of magmatic acid volatiles (i.e. presence of HF, $\mathrm{SO}_{2}$ ) [7], mineral precipitation, dissolution, ion exchange and adsorption [13-17].

Deep-sea hydrothermal fluids are enriched in REE over seawater by factors of $10-10^{3}$ [18]. With some exceptions, such as the Satanic Mills fluid and Fenway fluid in PACMANUS (Papua New Guinea-Australia-Canada-Manus), the acid-sulfate fluids from Desmos and North $\mathrm{Su}$, some smoker fluids from Suzette and South $\mathrm{Su}$, and some lowtemperature diffuse flows on MAR $15^{\circ} \mathrm{N}, \mathrm{MAR} 5^{\circ} \mathrm{S}$ and MAR $9^{\circ} \mathrm{S}$, deep-sea hydrothermal fluids have remarkably uniform $\mathrm{REE}_{\mathrm{N}}$ distribution patterns characterized by a LREE 
enrichment and a large, positive Eu anomaly [7,14,19-23].

REE contents in geothermal fluids can range over at least four orders of magnitude, from below detection up to $10^{-1}$ times those of chondrite [24]. There are three main endmember geothermal fluid types: (1) Low-pH acid sulfate fluids. Some are produced by atmospheric and microbial oxidation of $\mathrm{H}_{2} \mathrm{~S}$, such as the acidic geothermal waters from Rotokawa in New Zealand, from Yellowstone National Park and from Tatun volcanic area in Taiwan [6,25,26], and some are formed by mixing of deep steam, $\mathrm{CO}_{2}$ and $\mathrm{H}_{2} \mathrm{~S}$ with shallow groundwater, such as the acidic geothermal waters from Valles Caldera in New Mexico and from Dominica [27]. In addition, some are the result of the release of the magmatic gases $\mathrm{HCl}$ and $\mathrm{SO}_{2}$, such as the Ruapehu Crater lake in New Zealand and the Obuki acid hot spring waters from the Tamagawa geothermal area in Japan $[11,25,28]$; (2) neutral-chloride fluids, which may have a magmatic component and are usually representative of deep fluid in a geothermal area, such as fluids from Waikite in New Zealand and hot spring waters at Dagangshan in Taiwan [6,29]; and (3) bicarbonate-carbonate-dominated fluids, which are the result of water/ $\mathrm{CO}_{2}$ interaction with reservoir rocks and have near-neutral to alkaline $\mathrm{pH}[29,30]$, such as fluids from hot springs at Hongye and Qingshui in Taiwan [6] and the geothermal thermal waters from Oregon, Nevada and California [9].

Because of the different geological conditions, the distributions of REE in fluids from continental geothermal fields are different from those of deep-sea hydrothermal fluids. Most acidic fluids from continental geothermal fields have a very distinctive "gull wing" pattern, which has a negative Eu anomaly [6,8,11,25,27,31], although some low$\mathrm{pH}$ hot waters show LREE enrichment and positive or no Eu anomalies [6,27].

Compared with the study of deep-sea hydrothermal fluids and hot waters from continental geothermal fields, there has been little research on the REE of marine hydrothermal fluids in shallow water. The only study that we know of is that of Pichler et al. [32], who studied the REE compositions of shallow-water hydrothermal fluids in Tutum Bay, where REE concentrations in vent waters are generally one order of magnitude higher than that of average seawater. The North American Shale Composite normalized REE distribution patterns of some fluids showed an initial drop from La to $\mathrm{Ce}$ followed by a rise from the $\mathrm{Ce}$ minimum to a $\mathrm{Eu}$ maximum and a slight decrease towards an intermediate Lu. The other fluids showed an initial drop from La to Ce followed by a rise from the Ce minimum to a Dy maximum and a slight decrease towards $\mathrm{Lu}$.

Although the enrichment of REE in hydrothermal fluids reflects the interaction between the fluid and host rock $[7,11,15]$, experimental results have shown that the REE compositions of hydrothermal fluids are not inherited directly from the primary rocks with which the hydrothermal fluids interact. Instead they are controlled primarily by the physics and chemistry of the fluid (e.g. temperature, pH, redox, availability of ligands) [19,20,26,33-36], mineral precipitation and dissolution $[8,11,14,37]$, secondary mineral formation [38], and adsorption by solid particles [16,39].

Based on the characteristics of REE in vent fluids from Kueishantao hydrothermal field, the present study analyzed the factors causing different REE distribution patterns of the yellowish fluids and whitish fluids found there. Combined with previous results from deep-sea hydrothermal fluids, hot springs on continents and simulation experiments, we provide a better understanding of how REE in vent fluids could be used as tracers of sub-seafloor hydrothermal processes.

\section{Geological background}

Kueishantao is about $10.8 \mathrm{~km}$ from Wushi harbor at Toucheng town on Ilan plain. It is located at the southernmost part of the Okinawa Trough, which is generally considered to be an intercontinental back arc basin behind the Ryukyu arctrench system resulting from the subduction of the Philippine Sea plate beneath the Eurasian plate [40]. Kueishantao is the last volcanic center toward the southwest along the spreading axis of the Okinawa Trough [41], and it is composed of andesite, including lava flows and pyroclastics [42]. Kueishantao is located on a N-S-trending extensional structure, and a clear seismic zone exists at depths shallower than $15 \mathrm{~km}$ [41]. In addition, there is a prominent low-velocity zone right beneath Kueishantao, indicating magmatic activity [43]. Chen et al. [42] reported a thermoluminescene (TL) age of $7 \pm 0.7 \mathrm{ka}$ for a siltstone xenolith found at Kueishantao. From the chemical and isotopic $\left({ }^{87} \mathrm{Sr} /{ }^{86} \mathrm{Sr}, \varepsilon \mathrm{Nd}\right.$ and $\left.\delta^{18} \mathrm{O}\right)$ compositions of fresh andesites, it has been inferred that the magma at Kueishantao is the product formed during the embryonic rift stage of the active back-arc basin and most likely results from a MORB-type magma assimilation with local continental crust materials and/or the thick overlying sediments $[41,44]$.

There are two kinds of fluids in Kueishantao hydrothermal field. One is yellowish fluid with temperature between 92 and $116^{\circ} \mathrm{C}$, and the other is whitish fluid having lower temperature of $48-62^{\circ} \mathrm{C}$ [45]. Magnesium and $\mathrm{SiO}_{2}$ data indicate that these hydrothermal fluids, which have high $\mathrm{CO}_{2}$ and $\mathrm{H}_{2} \mathrm{~S}$ but low $\mathrm{SO}_{2}$ and $\mathrm{HCl}$ contents, probably originate from a depth of 915-1350 $\mathrm{m}[45,46]$. The temperature of the fluids has a close correlation with the diurnal tides, reaching a maximum two to four hours after each high tide (high pressure) [47]. Native sulfur deposits are present in a number of different forms: as sand (hemispheres, soft, diameter $2 \mathrm{~mm}$, formed from the sedimentation of small sulfur particles), as chimneys (high sulfur content up to $99.13 \%$, originating from $\mathrm{H}_{2} \mathrm{~S}$ and $\mathrm{SO}_{2}$ produced by magma degassing, the sulfur content increasing from the outer layer to the inner layer of the chimney) [48-50], and balls (size as large as a softball, having obvious rings that can be readily 
distinguished by differences in color, their growth significantly slower than that of the native sulfur chimneys, having a "glue pudding" type of growth) [51].

\section{Methods}

\subsection{Sample collection}

The hydrothermal fluids and rock samples were collected on May 31,2011 . The yellow spring $\left(24.8349^{\circ} \mathrm{N}, 121.9619^{\circ} \mathrm{E}\right)$ is closer to Kueishantao than the white spring $\left(24.8341^{\circ} \mathrm{N}\right.$, $121.9619^{\circ} \mathrm{E}$ ) (Figure 2). Hydrothermal fluids were collected in $4 \mathrm{~L}$ Pyrex bottles at the seafloor (east of Kueishantao) by divers, two bottles for each spring vent. Shallow seawater was collected at a depth of $10 \mathrm{~m}$ near Kueiwei to exclude the hydrothermal influence. The temperature of the fluids and seawater and the flow rate were measured in situ. The methods of fluid collection, temperature determination in situ and flow estimation are described in detail in the Master's thesis of Guo [52]. Rocks near the vents were struck and sampled with a geological hammer. The aqueous samples were filtered into $1 \mathrm{~L}$ Naglen polypropylene bottles (previously soaked in $1: 1 \mathrm{HNO}_{3}$ for $48 \mathrm{~h}$, washed to neutral $\mathrm{pH}$ with distilled water and ultra-pure water in turn, then dried) on shore.

\subsection{Analytical methods}

On return to the shore laboratory, each aqueous sample was sub-sampled into three glass beakers $(50 \mathrm{~mL})$. Then the $\mathrm{pH}$ values were determined with a portable $\mathrm{pH}$ meter (JENCO 6010 , resolution $0.01 \mathrm{pH}$, automatic temperature compensation), and the averages were calculated. Before its use on samples, the $\mathrm{pH}$ meter was calibrated with buffer solutions of $\mathrm{pH} 4.00$ and 6.86 .

Chloride, sulfate and REE concentrations in the solutions were all analyzed at the Institute of Oceanology, Chinese Academy of Sciences. Chloride and sulfate were measured by ion chromatography (ICS-2500) with an anion exchange resin column (DIONEX AS12) rinsed with 370 (mg/L) $\mathrm{Na}_{2} \mathrm{CO}_{3}-84(\mathrm{mg} / \mathrm{L}) \mathrm{NaHCO}_{3}$ at a rinsing rate of $1.2 \mathrm{~mL} / \mathrm{min}$. The precision was $\pm 1 \%$.

REE in the aqueous samples were pre-concentrated $(\times 20)$ using a DIONEX MetPac CC-1 (packed with a 17- $\mu \mathrm{m}$ macroporous vinylbenzyl/divinylbenzene copolymer covalently bonded with iminodiacetic acid functional groups). REE were separated from the major elements by chromatography with $2.0-\mathrm{mol} / \mathrm{L} \mathrm{NH}_{4} \mathrm{Ac}$. Ba was also eliminated from the samples to avoid interference between $\mathrm{Ba}$ oxides and $\mathrm{Eu}$, and then the samples were eluted with $2-\mathrm{mol} / \mathrm{L}$ $\mathrm{HNO}_{3}$. In order to improve the reliability of the analysis, standard solutions $(0,1,5,10 \mu \mathrm{g} / \mathrm{L})$ were prepared to make a standard curve by pre-concentrating pure water $(\times 1), 2 \mu \mathrm{g} / \mathrm{L}$ multi-element standard $(\times 0.5, \times 2.5)$ and $20 \mu \mathrm{g} / \mathrm{L}$ multielement standard $(\times 0.5)$. The pre-concentration method is described in detail in the Master's thesis of Liu (2008) [53]. Then the REE in the liquid were determined by ICP-MS (ELAN DRC II), RSD $<5 \%$, recovery of $97 \%-108 \%$.

$\mathrm{Mg}$ in the water samples was determined by ICP-AES at

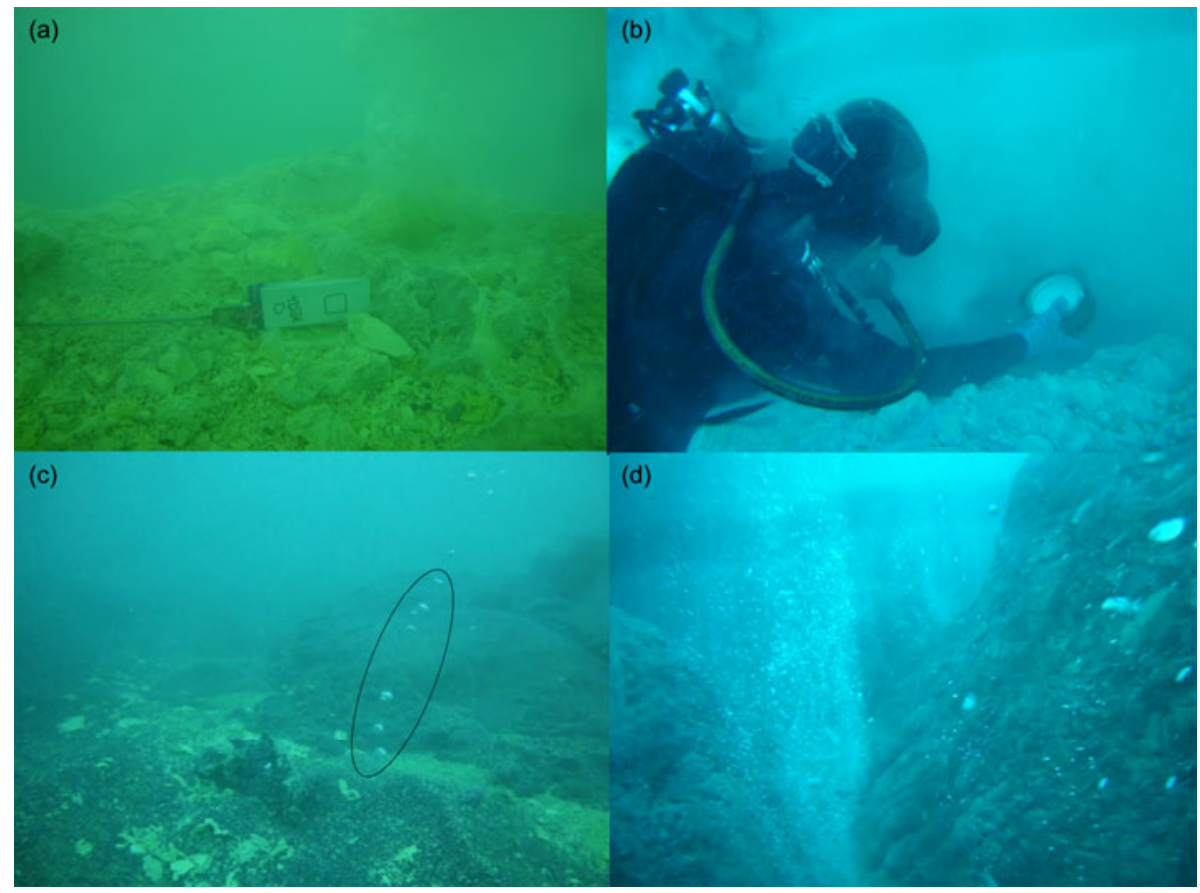

Figure 1 Photos of Kueishantao hydrothermal field. (a) Jetting of yellowish fluid $\left(108^{\circ} \mathrm{C}\right.$, flow rate of $\left.35 \mathrm{~m}^{3} / \mathrm{h}\right)$ with numerous fine sulfur particles and accumulation of native sulfur fragments around the yellow spring to form a mound; (b) diffuse flow of whitish fluid $\left(51^{\circ} \mathrm{C}\right.$, flow rate of $\left.19 \mathrm{~m} / \mathrm{h}\right)$ in a crack of base rock and no accumulation of native sulfur. This picture shows a diver measuring the fluid temperature in situ; (c) a bubble string dispersed sporadically near the yellow spring vent; (d) spectacular "bubble wall" near the white spring vent, which reflects more cracks relative to the yellow spring. 


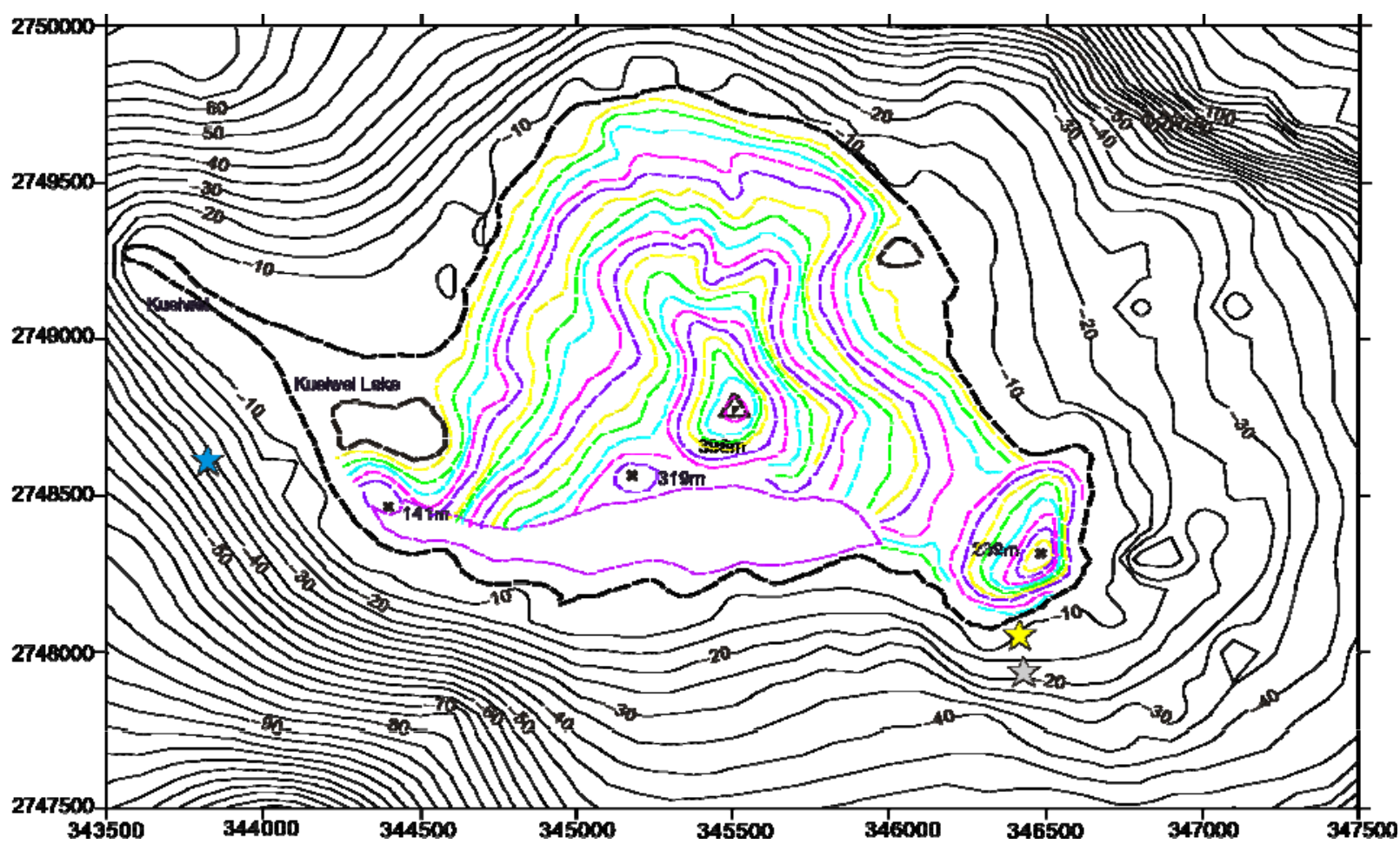

Figure 2 Bathymetric chart (m) of survey area off Kueishantao. The yellow spring (noted by a yellow pentagram) is located closer to Kueishantao at a water depth of $7.2 \mathrm{~m}$, and the white spring (noted by a gray pentagram) is located at a water depth of $15.1 \mathrm{~m}$ at a distance of $86 \mathrm{~m}$ from the yellow spring. The shallow seawater was collected at Kueiwei (noted by a blue pentagram). This figure is modified from the chart provided by Seawatch Company. The coordinate is TWD67.

the Experiment-Testing Center of Marine Geology, China Geological Survey Bureau, and the precision was $\pm 1 \%$. Like acid-sulfate fluids sampled from DESMOS and North Su, fluids sampled from the Kueishantao hydrothermal field have high $\mathrm{Mg}$ concentrations but very low $\mathrm{pH}$ (Table 1), so the concept of a zero-Mg end-member hydrothermal fluid does not apply [7], and the REE concentrations in the Kueishantao fluids were not extrapolated to zero $\mathrm{Mg}$ as they are for other deep-sea hydrothermal fluids.

Fresh rock chips were taken for analysis by examination under a binocular microscope to avoid any alteration. After mixed acid digestion, REE were analyzed by ICP-MS at the Institute of Oceanology, Chinese Academy of Sciences. BHVO-2 and BCR-2 (international standards), and GBW7315 and GBW7316 (domestic standards) were used. Except for $\mathrm{Eu}( \pm 5 \%)$ and $\mathrm{Lu}( \pm 4 \%)$, the precisions were between $\pm 1 \%$ and $\pm 3 \%$. Small particles filtered from the whitish fluids were observed and determined by scanning electron microscopy at Qingdao Institute of Bioenergy and Bioprocess Technology, Chinese Academy of Sciences.

\section{Results}

\subsection{Kueishantao hydrothermal fluids and precipitates}

Because of the dissolution of the acidic volcanic gases and the oxidation of $\mathrm{H}_{2} \mathrm{~S}$ [45], the yellowish fluids have very low $\mathrm{pH}$ values ( 2.81 and 2.29 at $25^{\circ} \mathrm{C}$ in this study) and are enriched in sulfate relative to shallow seawater (Table 1). By contrast, the $\mathrm{pH}$ values of the whitish fluids are 5.10 and 4.67 in this survey, which probably result from a greater infiltration of seawater under the seafloor induced by the greater number of cracks near the white spring (see "bubble wall", Figure 1(c) and (d)). The sulfate concentrations of the whitish fluids are consistent with those of the yellowish fluids and a little higher than those of the shallow seawater (Table 1).

A large amount of native sulfur precipitates from the yellowish fluid (Figure 1(a)), forming chimneys and accumulating as fragile fragments (Figure 3(a)) near the vent to form a mound. In contrast, there was no sulfur deposit near the white spring (Figure 1(b)). However, there were many milky-white small particles filtered from the whitish fluid, mainly composed of sulfur, aluminum and silicon, identified by scanning electron microscopy (Figure 3(b)).

\subsection{REE in Kueishantao hydrothermal fluids}

The $\Sigma$ REE concentrations of Kueishantao hydrothermal fluids are 813-1212 ng/L, 1-2 orders of magnitude higher than those of seawater ( $\Sigma$ REE of shallow seawater is $92 \mathrm{ng} / \mathrm{L}$; $\Sigma$ REE of deep seawater is $14 \mathrm{ng} / \mathrm{L}$ ). The $\mathrm{REE}_{\mathrm{N}}$ distribution patterns of the yellowish fluids show a slight enrichment of LREE and a slight convex-downward curvature at Eu. The 
Table 1 Rare earth concentrations in fluids sampled from the Kueishantao hydrothermal field

\begin{tabular}{|c|c|c|c|c|c|c|}
\hline \multirow{2}{*}{ Sample } & \multicolumn{2}{|c|}{ Yellowish fluids } & \multicolumn{2}{|c|}{ Whitish fluids } & \multirow{2}{*}{ Shallow seawater } & \multirow{2}{*}{ Deep seawater ${ }^{a}$} \\
\hline & Y-1 & $\mathrm{Y}-2$ & $\mathrm{~W}-1$ & $\mathrm{~W}-2$ & & \\
\hline $\mathrm{pH}\left(25^{\circ} \mathrm{C}\right)$ & 2.81 & 2.29 & 5.10 & 4.67 & 8.02 & \\
\hline$T\left({ }^{\circ} \mathrm{C}\right)$ & 108 & 108 & 51 & 51 & 25 & \\
\hline $\mathrm{La}(\mathrm{ng} / \mathrm{L})$ & 128 & 185 & 183 & 179 & 8 & 4.0 \\
\hline $\mathrm{Ce}(\mathrm{ng} / \mathrm{L})$ & 287 & 413 & 422 & 407 & 11 & 0.8 \\
\hline $\operatorname{Pr}(\mathrm{ng} / \mathrm{L})$ & 35 & 52 & 47 & 46 & 5 & 0.6 \\
\hline $\mathrm{Nd}(\mathrm{ng} / \mathrm{L})$ & 155 & 238 & 171 & 172 & 24 & 3.1 \\
\hline $\mathrm{Sm}(\mathrm{ng} / \mathrm{L})$ & 37 & 62 & 34 & 37 & 6 & 0.6 \\
\hline $\mathrm{Eu}(\mathrm{ng} / \mathrm{L})$ & 9 & 17 & 11 & 11 & 1 & 0.2 \\
\hline Gd (ng/L) & 41 & 65 & 36 & 37 & 6 & 1.0 \\
\hline $\mathrm{Tb}(\mathrm{ng} / \mathrm{L})$ & 7 & 10 & 7 & 6 & 1 & 0.1 \\
\hline Dy (ng/L) & 42 & 63 & 49 & 47 & 10 & 1.0 \\
\hline Ho (ng/L) & 9 & 13 & 11 & 10 & 2 & 0.3 \\
\hline $\operatorname{Er}(\mathrm{ng} / \mathrm{L})$ & 27 & 43 & 34 & 31 & 7 & 0.9 \\
\hline $\operatorname{Tm}(\mathrm{ng} / \mathrm{L})$ & 4 & 6 & 5 & 4 & 1 & - \\
\hline $\mathrm{Yb}(\mathrm{ng} / \mathrm{L})$ & 27 & 40 & 32 & 29 & 7 & 0.9 \\
\hline $\mathrm{Lu}(\mathrm{ng} / \mathrm{L})$ & 4 & 6 & 5 & 4 & 1 & 0.2 \\
\hline ¿REE (ng/L) & 813 & 1212 & 1045 & 1022 & 92 & 14 \\
\hline$(\mathrm{La} / \mathrm{Yb})_{\mathrm{N}}$ & 2.90 & 2.84 & 3.69 & 3.88 & 0.43 & 0.23 \\
\hline$\delta \mathrm{Eu}$ & 0.74 & 0.82 & 0.95 & 0.93 & 0.59 & 0.65 \\
\hline $\mathrm{Cl}(\mathrm{mg} / \mathrm{L})$ & 17372 & 18294 & 17797 & 17301 & 19357 & 19145 \\
\hline $\mathrm{SO}_{4}(\mathrm{mg} / \mathrm{L})$ & 3007 & 3122 & 2930 & 2949 & 2709 & 2690 \\
\hline $\operatorname{Mg}(\mathrm{mg} / \mathrm{L})$ & 1050 & 1089 & 1113 & 1113 & 1147 & 1288 \\
\hline
\end{tabular}

a) The REE data for deep seawater are from [19].

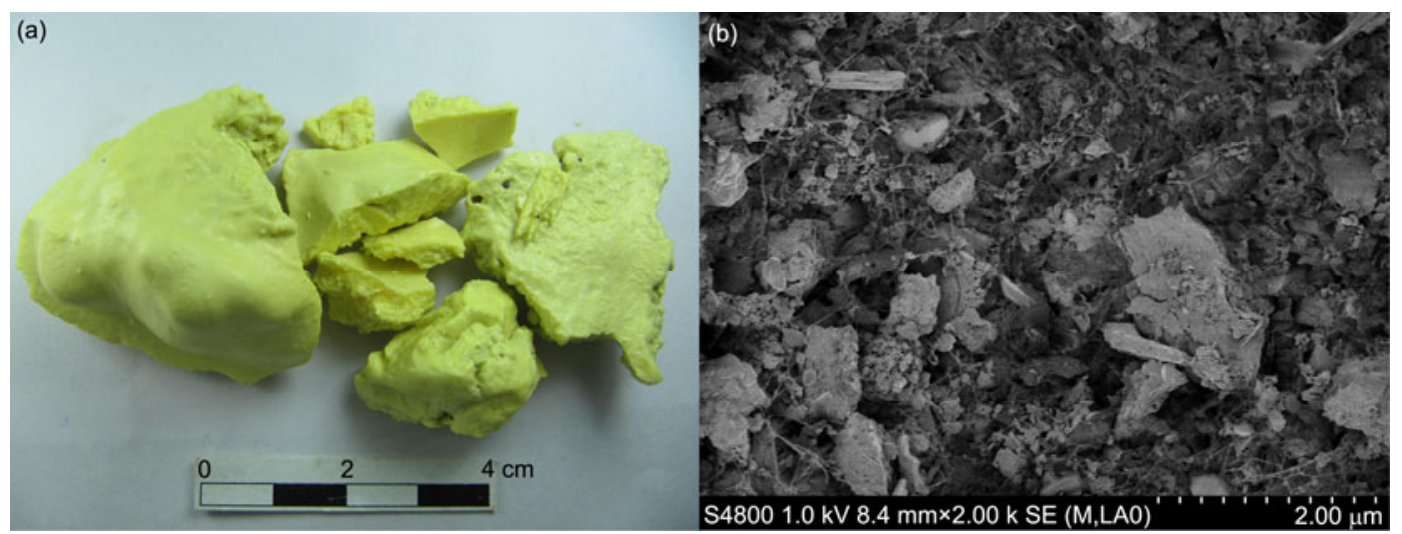

Figure 3 Precipitates from Kueishantao hydrothermal fluids. (a) Native sulfur fragments collected near the yellowish fluid vent; (b) SEM photograph of small sulfur particles filtered from the whitish fluids.

whitish fluids have $\mathrm{REE}_{\mathrm{N}}$ distribution patterns that exhibit a higher enrichment of LREE than those of the yellowish fluids and without Eu anomalies (Figure 4). The $\mathrm{REE}_{\mathrm{N}}$ distribution patterns of Kueishantao fluids are different from those of shallow seawater (generally flat with a negative Ce anomaly) (Figure 4), deep-sea acid-sulfate fluids (Figure $5(\mathrm{a})$ ), the acid-sulfate fluids in Taiwan Tatun volcanic area
(Figure 5(b)) and other acid-sulfate hot waters in continental geothermal fields (Figure 5(c)).

\subsection{REE in Kueishantao andesites}

According to the distribution of REE, there seem to be two kinds of andesites in the Kueishantao hydrothermal field, 


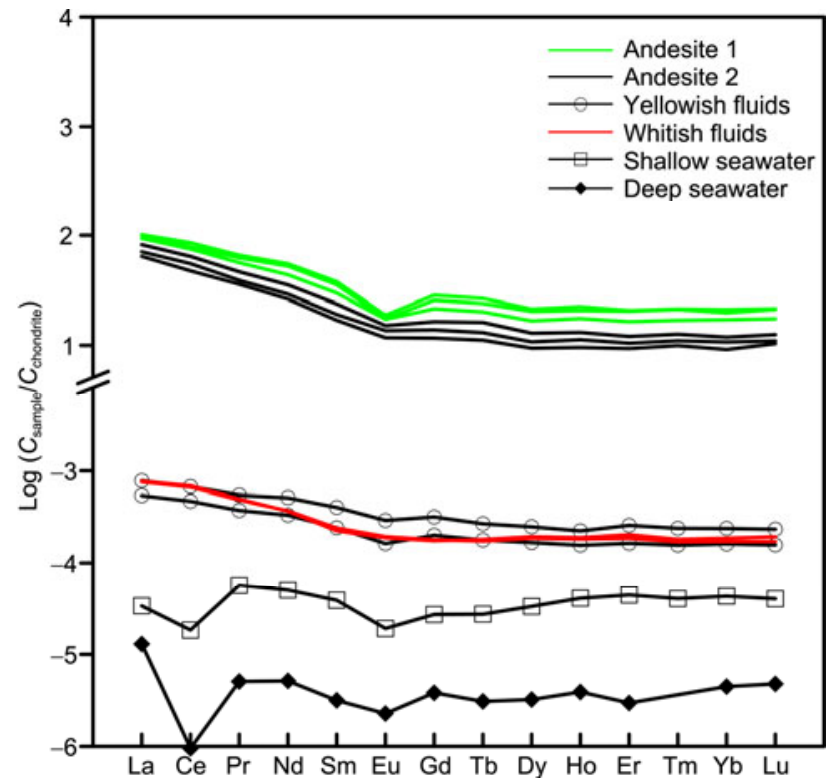

Figure 4 Chondrite-normalized REE distribution patterns of Kueishantao hydrothermal fluids, andesites at the seafloor, shallow seawater and deep seawater. The chondrite data are from [54].

one (andesite 1) having higher $\Sigma$ REE (116-137 mg/kg), the other (andesite 2) having lower $\Sigma$ REE (73-97 mg/kg). The $\mathrm{REE}_{\mathrm{N}}$ distribution patterns of andesite 1 and andesite 2 both show LREE enrichment, but andesite 1 has a more obvious negative Eu anomaly than andesite 2 (Figure 4). Compared with the yellowish and whitish fluids, Kueishantao andesites have higher LREE/HREE ratios and larger negative Eu anomalies (Tables 1 and 2).

\section{Discussions}

\section{1 $\Sigma$ REE concentrations in Kueishantao fluids}

The $\Sigma$ REE concentrations in Kueishantao fluids are lower than they are in most deep-sea hydrothermal fluids [56] and acidic hot waters in continental geothermal fields $[8,11,25$, 27,31]. The difference may be caused by the low leaching efficiency under the seafloor due to the short duration of fluid-andesite interaction in the Kueishantao hydrothermal field [45].

The $\mathrm{pH}$ is the dominant control on REE concentration. The REE enrichment of the solutions increases with decreasing $\mathrm{pH}[9,24,26]$, so the yellowish fluids ( $\mathrm{pH}$ values of 2.29 and 2.81) should have higher RREE concentrations than the whitish fluids ( $\mathrm{pH}$ values of 5.10 and 4.67). However, the yellowish and whitish fluids have similar $\Sigma$ REE concentrations as a result of three processes: (1) the faster flow of the yellowish fluids (the flux is $35 \mathrm{~m}^{3} / \mathrm{h}$, nearly twice that of whitish fluids), leading to shorter water-rock interaction times beneath the seafloor; (2) the boiling of fluid, causing loss of REE [9,29], the temperature of the yellowish fluids $\left(108^{\circ} \mathrm{C}\right)$ almost reaching the theoretical boiling point of $123^{\circ} \mathrm{C}$ for this depth [45]; (3) the precipitation of native sulfur, which enriches REEs, e.g. $\Sigma$ REE concentrations of native sulfur chimneys of $4.46-21.00 \mu \mathrm{g} / \mathrm{kg}$ [49], about 4-20 times higher than those of the hydrothermal fluids.

\section{2 $\delta$ Eu of Kueishantao fluids}

In low-temperature experiments, acidic fluids interacting with fresh or slightly weathered andesite often have an obvious negative Eu anomaly [8], such as occurs in many acidsulfate hydrothermal fluids in continental geothermal fields (Figure 5(c)). However, not all low-temperature acid-sulfate fluids discharging from andesite host rocks have significant negative Eu anomalies. For example, the Desmos acid-sulfate fluids in Manus Basin have a slight convex-upward curvature at $\mathrm{Eu}(\delta \mathrm{Eu}$ is 1.18-1.31) (Figure 5(a)). Some acid-sulfate fluids in Taiwan Tatun volcanic area have flat patterns at Eu ( $\delta$ Eu is 0.94-1.06) (Figure 5(b)), and the Kueishantao
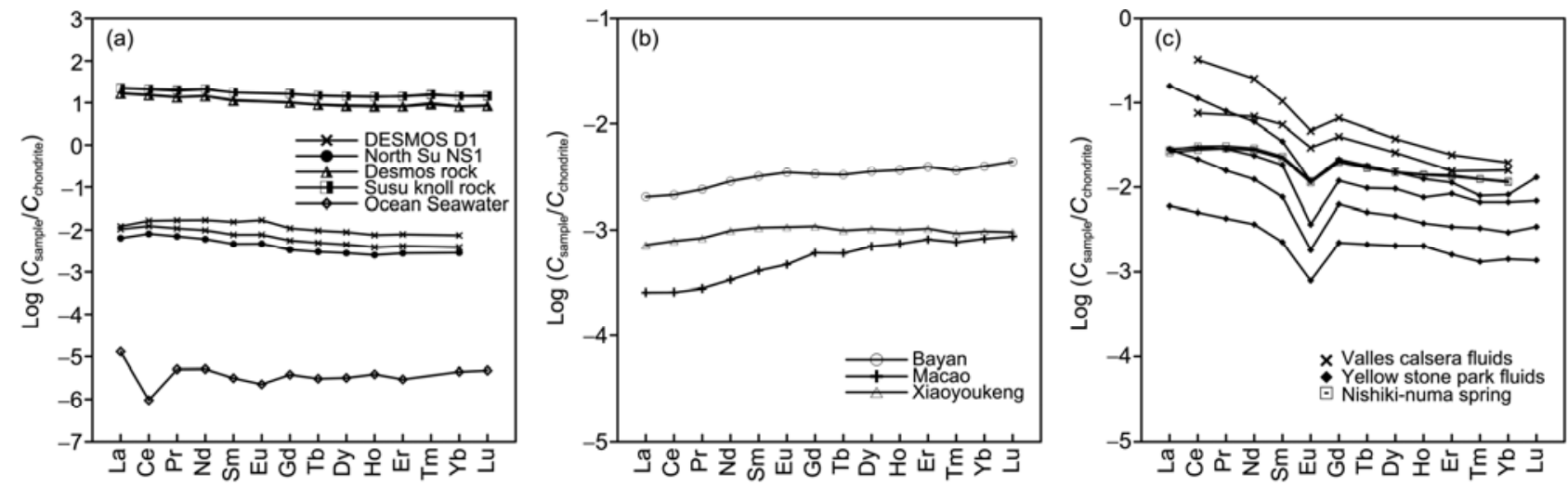

Figure $5 \mathrm{REE}_{\mathrm{N}}$ distribution patterns of acid-sulfate fluids in deep-sea and continental geothermal fields. (a) The patterns of acid-sulfate fluids, host rocks, and deep seawater in Eastern Manus Basin (fluid data from [7], host rock data from [55], deep seawater data from [19]); (b) the patterns of acid-sulfate fluids in Taiwan Tatun volcanic area (data from [6]); (c) the patterns of acid-sulfate fluids in Yellowstone National Park, New Mexico Valles Caldera and Hokkaido Nishiki-numa in Japan (data from $[8,27,31])$. 
Table 2 Rare earth element concentrations in andesites sampled from Kueishantao hydrothermal field (Unit: $\mathrm{mg} / \mathrm{kg}$ )

\begin{tabular}{|c|c|c|c|c|c|c|}
\hline \multirow{3}{*}{ Sample } & \multicolumn{6}{|c|}{ Andesite Rock } \\
\hline & \multicolumn{3}{|c|}{ Andesite 1} & \multicolumn{3}{|c|}{ Andesite 2} \\
\hline & K11-Y5-R1-1 & K11-Y5-R2-1 & K11-Y5-R2-3 & K11-W0-R1-1 & K11-W0-R2-1 & K11-W2-R1-1 \\
\hline $\mathrm{La}$ & 22.14 & 23.97 & 23.74 & 16.72 & 19.42 & 15.21 \\
\hline $\mathrm{Ce}$ & 45.78 & 52.25 & 48.03 & 33.69 & 39.2 & 28.98 \\
\hline $\operatorname{Pr}$ & 5.34 & 6.24 & 5.89 & 3.69 & 4.41 & 3.4 \\
\hline $\mathrm{Nd}$ & 20.39 & 25.65 & 24.44 & 13.59 & 16.51 & 12.27 \\
\hline $\mathrm{Sm}$ & 4.56 & 5.79 & 5.43 & 2.92 & 3.64 & 2.59 \\
\hline $\mathrm{Eu}$ & 1 & 1.09 & 1.01 & 0.79 & 0.88 & 0.68 \\
\hline $\mathrm{Gd}$ & 4.42 & 5.86 & 5.28 & 2.84 & 3.37 & 2.4 \\
\hline $\mathrm{Tb}$ & 0.75 & 1 & 0.9 & 0.49 & 0.6 & 0.42 \\
\hline Dy & 4.24 & 5.43 & 5.17 & 2.74 & 3.28 & 2.4 \\
\hline Ho & 0.99 & 1.27 & 1.17 & 0.64 & 0.74 & 0.54 \\
\hline $\mathrm{Er}$ & 2.72 & 3.43 & 3.38 & 1.74 & 2 & 1.55 \\
\hline $\mathrm{Tm}$ & 0.43 & 0.55 & 0.54 & 0.28 & 0.32 & 0.25 \\
\hline $\mathrm{Yb}$ & 2.91 & 3.59 & 3.36 & 1.82 & 2.02 & 1.56 \\
\hline $\mathrm{Lu}$ & 0.44 & 0.55 & 0.54 & 0.28 & 0.32 & 0.26 \\
\hline$\Sigma \mathrm{REE}$ & 116.11 & 136.65 & 128.87 & 82.22 & 96.72 & 72.52 \\
\hline$(\mathrm{La} / \mathrm{Yb})_{\mathrm{N}}$ & 5.46 & 4.79 & 5.07 & 6.57 & 6.9 & 6.99 \\
\hline$\delta \mathrm{Eu}$ & 0.68 & 0.57 & 0.58 & 0.84 & 0.77 & 0.84 \\
\hline
\end{tabular}

acid-sulfate fluids we investigated have a slight negative $\mathrm{Eu}$ anomaly or no Eu anomaly ( $\delta \mathrm{Eu}$ values of yellowish fluids are 0.74 and $0.82 ; \delta \mathrm{Eu}$ values of whitish fluids are 0.95 and 0.93 ) (Figure 4). These results imply that there are other factors affecting the relative concentration of Eu in Kueishantao hydrothermal fluids besides the water-rock interaction.

The Kueishantao yellowish fluids have a slight Eu anomaly, which may be related to the lower temperature $\left(108^{\circ} \mathrm{C}\right)$. Temperature is important to the dependence of the $\mathrm{Eu}^{3+} / \mathrm{Eu}^{2+}$ ratio on redox potential, and low temperature favors trivalent Eu [34,39]. Moreover, calculations of REE species distribution suggest that in some acid-sulfate fluids $\left(<120^{\circ} \mathrm{C}\right)$ the REE are present in solution predominantly as free trivalent ions [7]. Therefore, at the low temperatures characteristic of the Kueishantao yellowish fluids, Eu can occur in the trivalent form, the same as other REE, so the negative Eu anomaly would be weakened or be almost absent.

As more cracks exist near the white spring, relatively oxidizing seawater infiltrates and mixes with fluid under the seafloor, increasing the oxidation and decreasing the temperature of the whitish fluids. As a result, Eu is present as $\mathrm{Eu}$ (III), and no Eu anomaly occurs in the whitish fluids, owning to the lower temperatures (average $51^{\circ} \mathrm{C}$ ) and higher oxidation state.

\subsection{Complexation of REE in Kueishantao fluids}

Kueishantao hydrothermal fluids have high Al contents [45], which may inhibit REE-fluoride complex formation by forming Al-fluoride complexes [57]. Moreover, the very low $\mathrm{pH}$ of the yellowish fluids would mean that fluorine is present as $\mathrm{HF}$, minimizing the quantity of $\mathrm{F}^{-}$ions available for complexation [19]. Therefore, REE-fluoride complexes do not contribute to aqueous REE species in the Kueishantao hydrothermal fluids.

The REE-sulfate and REE-chloride complexes are irrelevant to the enrichment of REE in acid-sulfate fluids (low $\mathrm{pH}$ and sulfate-enriched) [7] and would then have little effect on the REE distribution in the Kueishantao yellowish fluids (average pH 2.55). However, concentrations of REE in the whitish fluids $\left(51^{\circ} \mathrm{C}\right.$ and average $\left.\mathrm{pH} 4.89\right)$ could be affected by REE-chloride complexes. As shown by experiments and calculations, the stabilities of LREE $\left(\mathrm{La}^{3+}\right)$-sulfate complexes are similar to those of HREE $\left(\mathrm{Lu}^{3+}\right)$-sulfate complexes at 25 and $300^{\circ} \mathrm{C}$, saturated water vapor pressure [58], while the stabilities of LREE $\left(\mathrm{La}^{3+}\right)$-chloride complexes are higher than those of HREE $\left(\mathrm{Lu}^{3+}\right)$-chloride complexes at all temperatures, 25,200 and $300^{\circ} \mathrm{C}$, saturated water vapor pressure $[35,58]$. These results imply that the formation of REE-sulfate complexes can not fractionate LREE and HREE, whereas the formation of REE-chloride complexes may give rise to the LREE enrichment in the whitish fluids.

\subsection{Fractionation of REE in Kueishantao fluids}

At very low $\mathrm{pH}(<1.5-2)$, REE from rock or magma show 
little fractionation across the entire series, whereas waters with $\mathrm{pH}$ in the range 2-4 tend to show fractionation of the LREE [25]. Therefore, the Kueishantao yellowish fluids (pH 2.29 and 2.81) have a slight LREE enrichment, (La/ $\mathrm{Yb})_{\mathrm{N}}$ of 3.34 and 3.28 , but their $\mathrm{REE}_{\mathrm{N}}$ distribution patterns are flatter than those of the host andesites (4.79-6.99), indicating that besides low $\mathrm{pH}$, there are other factors affecting the fractionation between the LREE and HREE. One factor might be the formation of native sulfur. The LREE/HREE ratios of native sulfur in a chimney formed from the yellowish fluid are much higher than that of the yellowish fluid and $(\mathrm{La} / \mathrm{Yb})_{\mathrm{N}}$ is up to 6.61-9.80 [49]. The fractionation between HREE $\left(\mathrm{Gd}_{\mathrm{N}} / \mathrm{Yb}_{\mathrm{N}}\right.$ is $\left.1.10-1.48\right)$ of the chimney is similar to those of yellowish fluid (1.24 and 1.33), implying that the precipitation of native sulfur causes the LREE to be mobilized from fluid more easily than the HREE, leading to a decrease in the LREE/HREE ratio of the yellowish fluid.

The $\mathrm{REE}_{\mathrm{N}}$ distribution patterns of Kueishantao whitish fluids ( $\mathrm{pH} 5.10$ and 4.67) exhibit a slight enrichment of LREE relative to HREE, and the $(\mathrm{La} / \mathrm{Yb})_{\mathrm{N}}$ ratios are 4.13 and 4.42. The adsorption of small, milky-white particles may be significant for the enrichment of LREE. Fluids with $\mathrm{pH}>4$ have a significant particulate REE load [16], and in fluid-rock interaction under mildly acidic conditions the REE pattern of the fluid is controlled by sorption processes (strength of sorption: $\mathrm{La}^{3+}<\mathrm{Eu}^{3+}<\mathrm{Lu}^{3+}$ ), which lead to (La/ $\mathrm{Lu})_{\mathrm{N}}>1[39]$.

\section{Conclusions}

The REE in Kueishantao hydrothermal fluids originate from host andesite. Their concentrations are lower than those of most deep-sea hydrothermal fluids and acidic hot waters in continental geothermal fields. The lower concentrations may be related to the short duration of fluid-andesite interaction under the seafloor, the boiling of fluid and the precipitation of sulfur minerals near the seafloor. The $\mathrm{REE}_{\mathrm{N}}$ distribution patterns of the yellowish fluids exhibit a slight convex-downward curvature at $\mathrm{Eu}$, and those of the whitish fluids have no Eu anomaly. The Eu anomalies of Kueishantao hydrothermal fluids are controlled mainly by the lower temperature and relative oxidizing conditions. Both yellowish fluids and whitish fluids show a slight enrichment of LREE. The fractionation between LREE and HREE of the yellowish fluids is influenced mainly by the very low $\mathrm{pH}$ and the precipitation of native sulfur. In contrast, the LREE/HREE ratios of the whitish fluids are related to the adsorption by small sulfur particles and the formation of REE-chloride complexes.

The authors thank Bing-Jye Wang and Sea-watch Company for sampling the hydrothermal fluids and rocks. This work was supported by the National Natural Science Foundation of China (40906029), the National Basic Research Program of China (2013CB429703), the Shandong Provincial
Natural Science Foundation of China for Distinguished Young Scholars (JQ200913), and the Open Fund of the Key Laboratory of Marine Geology and Environment, Chinese Academy of Sciences (MGE2011KG11).

1 Zeng Z G, Jiang F Q, Qin Y S, et al. Rare earth element geochemistry of massive sulfides from the Jade hydrothermal field in the Central Okinawa Trough (in Chinese). Acta Geol Sin, 2001, 75: 244-249

2 Dubinin A V. Geochemistry of rare earth elements in the Ocean. Lithol Miner Resour, 2004, 39: 289-307

3 Chudaev O, Chudaeva V, Sugimori K, et al. Composition and origin of modern hydrothermal systems of the Kuril island arc. Indian J Mar Sci, 2008, 37: 166-180

4 Elderfield $\mathrm{H}$. The oceanic chemistry of the rare-earth elements. Phil Trans R Soc Lond A, 1988, 325: 105-126

5 Zhang J, Nozaki Y. Behavior of rare earth elements in seawater at the ocean margin: A study along the slopes of the Sagami and Nankai troughs near Japan. Geochim Cosmochim Acta, 1998, 62: 1307-1317

6 Ye Y L. Rare earth element concentrations and patterns in Taiwan hot springs (in Chinese). Dissertation for the Master's Degree. Taiwan: Cheng Kung University, 2008. 34-60

7 Craddock P R, Bach W, Seewald J S, et al. Rare earth element abundances in hydrothermal fluids from the Manus Basin, Papua New Guinea: Indicators of sub-seafloor hydrothermal processes in backarc basins. Geochim Cosmochim Acta, 2010, 74: 675-683

8 Bau M, Usui A, Pracejus B, et al. Geochemistry of low-temperature water-rock interaction: Evidence from natural waters, andesite, and ironoxyhydroxide precipitates at Nishiki-numa iron-spring, Hokkaido, Japan. Chem Geol, 1998, 151: 293-307

9 Wood S A, Shannon W M. Rare-earth elements in geothermal waters from Oregon, Nevada, and California. J Solid State Chem, 2003, 171: 246-253

10 Liu Y G, Meng X W, Fu Y X. Rare earth element and strontium-neodymium isotope characteristics of hydrothermal chimney in Jade area in the Okinawa Trough (in Chinese). Acta Oceanol Sin, 2005, 27: 67-72

11 Sanada T, Takamatsu N, Yoshiike Y. Geochemical interpretation of long-term variations in rare earth element concentrations in acidic hot spring waters from the Tamagawa geothermal area, Japan. Geothermics, 2006, 35: 141-155

12 Tao C H, Li H M, Huang W, et al. Mineralogical and geochemical features of sulfide chimneys from the $49^{\circ} 39^{\prime} \mathrm{E}$ hydrothermal field on the Southwest Indian Ridge and their geological inferences. Chin Sci Bull, 2011, 56: 2828-2838

13 Sverjensky D A. Europium redox equilibria in aqueous solution. Earth Planet Sci Lett, 1984, 67: 70-78

14 Klinkhammer G P, Elderfield H, Edmond J M, et al. Geochemical implications of rare earth element patterns in hydrothermal fluids from mid-ocean ridges. Geochim Cosmochim Acta, 1994, 58: 5105-5113

15 Ding Z J, Liu C Q, Yao S Z, et al. Rare earth elements compositions of high-temperature hydrothermal fluids in sea floor and control factors (in Chinese). Adv Earth Sci, 2000, 15: 307-312

16 Wood S. The hydrothermal geochemistry of the rare earth elements. Gangue, 2004, 81: 1-7

17 Bao S X, Zhou H Y, Peng X T, et al. Rare earth element geochemistry of hydrothermal sulfide from Endeavour segment, Juan de Fuca Ridge (in chinese). Geochimica, 2007, 36: 303-310

18 Mitra A, Elderfield H, Greaves M J. Rare earth elements in submarine hydrothermal fluids and plumes from the Mid-Atlantic Ridge. Mar Chem, 1994, 46: 217-235

19 Douville E, Bienvenu P, Charlou J L, et al. Yttrium and rare earth elements in fluids from various deep-sea hydrothermal systems. Geochim Cosmochim Acta, 1999, 63: 627-643

20 Douville E, Charlou J L, Oelkers E H, et al. The rainbow vent fluids $\left(36^{\circ} 14^{\prime} \mathrm{N}, \mathrm{MAR}\right)$ : The influence of ultramafic rocks and phase separation on trace metal content in Mid-Atlantic Ridge hydrothermal fluids. Chem Geol, 2002, 184: 37-48

21 Schmidt K, Koschinsky A, Garbe-Schönberg D, et al. Geochemistry of hydrothermal fluids from the ultramafic-hosted Logatchev hydro- 
thermal field, $15^{\circ} \mathrm{N}$ on the Mid-Atlantic Ridge: Temporal and spatial investigation. Chem Geol, 2007, 242: 1-21

22 Hongo Y, Obata H, Gamo T, et al. Rare earth elements in the hydrothermal system at Okinawa Trough back-arc basin. Geochem J, 2007, 41: 1-15

23 Bau M, Balan S, Schmidt K, et al. Rare earth elements in mussel shells of the Mytilidae family as tracers for hidden and fossil hightemperature hydrothermal systems. Earth Planet Sci Lett, 2010, 299: 310-316

24 Shannon W M, Wood S A, Brown K, et al. Behavior of rare earth elements in geothermal systems: A new exploration/exploitation tool? Exploration Technology, Geothermal Energy R\&D Program, 2001, 2-31

25 Wood S A. Rare earth element systematics of acidic geothermal waters from the Taupo Volcanic Zone, New Zealand. J Geochem Explor, 2006, 89: 424-427

26 Lewis A J, Komninou A, Yardley B W D, et al. Rare earth element speciation in geothermal fluids from Yellowstone National Park, Wyoming, USA. Geochim Cosmochim Acta, 1998, 62: 657-663

27 Michard A. Rare earth element systematics in hydrothermal fluids. Geochim Cosmochim Acta, 1989, 53: 745-750

28 Yoshiike Y. Variation in the chemical composition of Obuki Spring, Tamagawa Hot Springs (1951-2000). Geochem J, 2003, 37: 649-662

29 Shannon W M, Wood S A, Brown K, et al. REE contents and speciation in geothermal fluids from New Zealand. In: Proceedings of the 10th International Symposium on Water-Rock Interaction.Villasimius: Balkema, 2001. 1001-1004

30 Arnórsson S, Stefánsson A, Bjarnason Jón Őrn. Fluid-fluid interactions in geothermal systems. Rev Mineral Geochem, 2007, 65: 259312

31 Lewis A J, Palmer M R, Sturchio N C, et al. The rare earth element geochemistry of acid-sulphate and acid-sulphate-chloride geothermal systems from Yellowstone National Park, Wyoming, USA. Geochim Cosmochim Acta, 1997, 61: 695-706

32 Pichler T, Veizer J, Hall G E M. The chemical composition of shallow-water hydrothermal fluids in Tutum Bay, Ambitle Island, Papua New Guinea and their effect on ambient seawater. Mar Chem, 1999, 64: 229-252

33 Migdisov A A, Willianms-Jones A E, Wagner T. An experimental study of the solubility and speciation of the rare earth elements (III) in fluoride- and chloride-bearing aqueous solutions at temperatures up to $300^{\circ} \mathrm{C}$. Geochim Cosmochim Acta, 2009, 73: 7087-7109

34 Hass J R, Shock E L, Sassani D C. Rare earth elements in hydrothermal systems: Estimates of standard partial molal thermodynamic properties of aqueous complexes of the rare earth elements at high pressures and temperatures. Geochim Cosmochim Acta, 1995, 59: $4329-4350$

35 Gammons C H, Wood S A, Youning L. Complexation of the rare earth elements with aqueous chloride at 20 and $300^{\circ} \mathrm{C}$ and saturated water vapor pressure. Geol Soc Spec Publ, 2002, 7: 191-207

36 Gammons C H, Wood S A, Williams-Jones A E. The aqueous geochemistry of the rare earth elements and yttrium: VI Stability of neodymium chloride complexes from 25 to $300^{\circ} \mathrm{C}$. Geochim Cosmochim Acta, 1996, 60: 4615-4630

37 Campbell A C, Palmer M R, Klinkhammer G P, et al. Chemistry of hot springs on the Mid-Atlantic Ridge. Nature, 1988, 335: 514-519

38 Allen D E, Seyfried J W E. REE controls in ultramafic hosted MOR hydrothermal systems: An experimental study at elevated temperature and pressure. Geochim Cosmochim Acta, 2005, 69: 675-683

39 Bau M. Rare-earth element mobility during hydrothermal and meta- morphic fluid-rock interaction and the significance of the oxidation state of europium. Chem Geol, 1991, 93: 219-230

40 Chiu C L, Song S R, Hsieh Y C, et al. Volcanic characteristics of Kueishantao in northeast Taiwan and their implications. Terr Atmos Ocean Sci, 2010, 21: 575-585

41 Chen C H, Lee T, Shieh Y N, et al. Magmatism at the onset of backarc basin spreading in the Okinawa Trough. J Volcanol Geotherm Res, 1995, 69: 313-322

42 Chen Y G, Wu W S, Chen $\mathrm{C} \mathrm{H}$, et al. A date for volcanic eruption inferred from a siltstone xenolith. Quat Sci Rev, 2001, 20: 869-873

43 Yeh Y H, Lin C H, Roecker S W. A study of upper crustal structures beneath northeastern Taiwan: Possible evidence of the western extension of Okinawa Trough. Proc Geol Soc Chin, 1989, 32: 139-156

44 Chung S L, Wang S L, Shinjo R, et al. Initiation of arc magmatism in an embryonic continental rifting zone of the southernmost part of Okinawa Trough. Terr Nova, 2000, 12: 225-230

45 Chen C T A, Wang B J, Huang J F, et al. Investigation into extremely acidic hydrothermal fluids off Kueishan Tao, Taiwan, China. Acta Oceanol Sin, 2005, 24: 125-133

46 Yang T F, Lan T F, Lee H F, et al. Gas compositions and helium isotopic ratios of fluid samples around Kueishantao, NE offshore Taiwan and its tectonic implications. Geochem J, 2005, 39: 469-480

47 Chen C T A, Zeng Z G, Kuo F W, et al. Tide-influenced acidic hydrothermal system offshore NE Taiwan. Chem Geol, 2005, 224: 6981

48 Liu C H, Zeng Z G, Yin X B, et al. Basic characters of native sulfur chimneys near the sea off Kuishantap from Northeastern Taiwan (in Chinese). J Oceanogr Taiwan Strait, 2006, 25: 309-317

49 Zeng Z G, Liu C H, Chen $\mathrm{C} \mathrm{T} \mathrm{A}$, et al. Origin of a native sulfur chimney in the Kueishantao hydrothermal field, offshore northeast Taiwan. Sci China Earth Sci, 2007, 50: 1746-1753

50 Liu C H, Zeng Z G. Sulfur isotope of submarine sulfur chimneys near Kueishan Island (in Chinese). Ocean Limn Sin, 2007, 38: 118-123

51 Zeng Z G, Chen C T A, Yin X B, et al. Origin of native sulfur ball from the Kueishantao hydrothermal field offshore northeast TaiwanEvidence from trace and rare earth element composition. J Asian Earth Sci, 2011, 40: 661-671

52 Guo F W. Preliminary investigation of the hydrothermal activities off Kueishantao Island (in Chinese). Dissertation for the Master's Degree. Taiwan: Sun Yat-Sen University, 2001. 12-15

53 Liu G. Experimental evaluation of yttrium and rare earth element (YREE) coprecipitation with calcium carbonates in seawater at 5, 15, $25^{\circ} \mathrm{C}$ and $1 \mathrm{~atm}$., and low dissolved concentrations (in Chinese). Dissertation for the Doctoral Degree. Qingdao: Institute of Oceanology, Chinese Academy of Sciences, 2008. 44-47

54 Sun S S, McDonough W F. Chemical and isotopic systematics of oceanic basalts: Implications for mantle composition and processes. Geol Soc Spec Publ, 1989, 42: 313-345

55 Park S H, Lee S M, Kamenov G D, et al. Tracing the origin of subduction components beneath the South East rift in the Manus Basin, Papua New Guinea. Chem Geol, 2010, 269: 339-349

56 Zeng Z G. Submarine Hydrothermal Geology (in Chinese). Beijing: Science Press, 2011. 289-300

57 Serrano M J G, Sanz L F A, Nordstrom D K. REE speciation in lowtemperature acidic waters and the competitive effects of aluminum. Chem Geol, 2000, 165: 167-180

58 Wood S. The aqueous geochemistry of the rare-earth elements and yttrium 2. Theoretical predictions of speciation in hydrothermal solutions to $350^{\circ} \mathrm{C}$ at saturation water vapor pressure. Chem Geol, 1990, 88: $99-125$

Open Access This article is distributed under the terms of the Creative Commons Attribution License which permits any use, distribution, and reproduction in any medium, provided the original author(s) and source are credited. 